DOI:

УДК 669.15-192.017:621.357.7

С.В. Колесник ${ }^{1}$ к.т.н., доцент, ievgen.kolesnyk@ukr.net

Г.А. Баглюк ${ }^{2}$, д.т.н., с.н.с., заступник директора

А.П. Сременко ${ }^{1}$, к.т.н., доцент

Є.С. Робак ${ }^{1}$, студентка

А.С. Усенко ${ }^{1}$, студентка

${ }^{1}$ Дніпровський державний технічний університет, м. Кам'янське

${ }^{2}$ Інститут проблем матеріалознавства ім. І. М. Францевича НАН України, м. Київ

\title{
ОПТИМІЗАЦІЯ ТЕХНОЛОГІЇ ЕЛЕКТРООСАДЖЕННЯ ПОКРИТТІВ Fe-Cr-Ni ЗА КРИТЕРІЕМ МІКРОТВЕРДОСТІ ПОВЕРХНІ
}

Показано вплив складу сульфатного електроліту на структурні параметри і мікротвеpдість електроосаджених сплавів системи $\mathrm{Fe}$-Cr-Ni. Виконано оптимізацію складу електроліту за критерієм мікротвердості поверхні досліджених покриттів. За результатами оптимізачії рекомендовано промислове використання сплаву $\mathrm{Fe}-\mathrm{Cr}-\mathrm{Ni}$ з підвищеною мікротвердістю поверхні для відновлення розмірів зночених сталевих деталей машин.

Ключові слова: електроосаджені покриття; сплави $\mathrm{Fe}-\mathrm{Cr}$-Ni; мікротвердість; мікроструктура; морфологія поверхні.

The influence of sulfate electrolyte composition on structural parameters and microhardness of electrodeposited alloys of $\mathrm{Fe}-\mathrm{Cr}$-Ni system is shown. The optimization of the electrolyte composition on criteria of surface microhardness is accomplished. On the basis of optimization the industrial usage of the $\mathrm{Fe}-\mathrm{Cr}$-Ni alloy with increased surface microhardness is recommended for restoration of dimensions of worn steel machine parts.

Keywords: electrodeposited coatings; $\mathrm{Fe}-\mathrm{Cr}$-Ni alloy; microhardness; microstructure; surface morphology.

\section{Постановка проблеми}

Електроосаджені покриття знайшли широке застосування у промисловості, зокрема електроосаджене залізо та деякі його сплави використовують для відновлення розмірів зношених під час експлуатації сталевих деталей машин різного призначення та типорозмірів [1]. Покриття, одержані способом електроосадження, мають підвищену твердість у порівнянні з матеріалами металургійного походження, тобто відновлення деталей за допомогою електроосаджених сплавів заліза (наприклад $\mathrm{Fe}-\mathrm{Cr}, \mathrm{Fe}-\mathrm{Ni}, \mathrm{Fe}-\mathrm{Mn}, \mathrm{Fe}-\mathrm{Cr}-\mathrm{Ni}$ ) одночасно приводить до їх поверхневого зміцнення, що $є$ додатковою перевагою цього способу ремонту деталей.

Для подальшого підвищення комплексу властивостей електроосаджених покриттів сплавами заліза і підвищення терміну використання деталей важкої техніки, що працюють в умовах тертя та зношування, актуальною задачею $\epsilon$ оптимізація технології їх одержання (складу електроліту, параметрів процесу електроосадження).

\section{Аналіз останніх досліджень та публікацій}

В попередніх дослідженнях проводилась чимала робота щодо вивчення структуроутворення двохкомпонентних електроосаджених сплавів на основі заліза, зокрема сплавів $\mathrm{Fe}-\mathrm{Cr}$ - [2-5], Fe-Ni — $[2,6-8], \mathrm{Fe}-\mathrm{Mn}-[9,10]$. Сумісний вплив хрому та нікелю на структуроутворення та мікротвердість електроосадженого заліза розглядався в роботі [11]. Процесам формування покриттів $\mathrm{Fe}-\mathrm{Cr}-\mathrm{Ni}$ присвячені також роботи [12-15]. В роботі [16] були проведені дослідження щодо впливу температури електроліту і катодної щільності струму на структуроутворення електроосадженого сплаву $\mathrm{Fe}-\mathrm{Cr}-\mathrm{Ni}$, в результаті яких з огляду на макроструктуру, морфологію поверхні та кристалографічну текстуру покриттів було визначено оптимальні значення цих параметрів процесу — температура $55^{\circ} \mathrm{C}$, щільність струму $10 \mathrm{~A} /$ дм $^{2}$.

Аналіз літературних джерел показав, що для електроосаджених сплавів системи $\mathrm{Fe}-\mathrm{Cr}$ $\mathrm{Ni}$ даних щодо впливу легуючих елементів та параметрів процесу електроосадження на мікрот- 
вердість поверхні покриттів представлено не достатньо, а однозначних закономірностей такого впливу досі не виявлено, що потребує подальших більш детальних досліджень.

\section{Формулювання мети дослідження}

Метою цієї роботи стало підвищення рівня властивостей електроосадженних покриттів економнолегованими сплавами $\mathrm{Fe}-\mathrm{Cr}-\mathrm{Ni}$ шляхом оптимізації технології їх одержання, зокрема складу електроліту. В якості критерію оптимізації обрано мікротвердість поверхні покриттів, оскільки, по-перше, мікротвердість відносно добре характеризує експлуатаційні властивості цього типу покриттів взагалі, а по-друге, вимірювання цієї характеристики не $є$ складними та $\epsilon$ достовірними.

\section{Виклад основного матеріалу}

Покриття завтовшки 15 мкм осаджували традиційним електрохімічним способом 3 електроліту складу: $\mathrm{FeSO}_{4} \cdot 7 \mathrm{H}_{2} \mathrm{O}-400$ г/л, $\mathrm{Al}_{2}\left(\mathrm{SO}_{4}\right)_{3} \cdot 18 \mathrm{H}_{2} \mathrm{O}-100$ г/л, $\mathrm{pH}=2-3$, в який додатково вводили хром та нікель у вигляді сульфатів $\left(\mathrm{Cr}_{2}\left(\mathrm{SO}_{4}\right)_{3} \cdot 6 \mathrm{H}_{2} \mathrm{O}\right.$ та $\mathrm{NiSO}_{4} \cdot 7 \mathrm{H}_{2} \mathrm{O}$ відповідно) у кількості від 0 до 20 г/л (у перерахунку на іони легуючого металу). Параметри процесу електролізу: катодна щільність струму $10 \mathrm{~A} /$ дм $^{2}$, температура електроліту $55^{\circ} \mathrm{C}$, анод - залізний, підкладка - промисловий сталевий лист 08кп без додаткової механічної обробки.

Товщину покриттів контролювали гравіметричним та мікроскопічним методами. Мікротвердість HV 0,05 вимірювали на приладі ПМТ-3 за стандартною методикою з використанням в якості індентора чотиригранної алмазної пірамідки з квадратною основою. Морфологію поверхні та мікроструктуру у поперечному перетині покриттів досліджували методом растрової електронної мікроскопії (мікроскоп РЭМ-106И), середній вміст легуючих елементів визначали на цьому ж приладі методом енергодисперсійного рентгеноспектрального мікроаналізу. Фазовий склад та кристалографічну текстуру оцінювали методом рентгенівської дифрактометрії (дифрактометр ДРОН-2) у мідному випромінюванні без відокремлення покриттів від сталевої підкладки.

Для порівняння впливу хрому та нікелю на структуроутворення та властивості електроосаджених сплавів на основі заліза спочатку одержували зразки покриттів 3 електролітів, що містять кожен з цих легуючих елементів окремо, а вже потім для виявлення їх спільного впливу осаджували покриття з електроліту з двома легуючими елементами. Елементний склад одержаних покриттів наведений в табл. 1. Фазовий склад всіх досліджених покриттів представлений лише твердими розчинами на основі $\alpha-\mathrm{Fe}$ (рис. 1).

Таблиия 1. Середній вміст легуючих елементів в електроосаджених покриттях в залежності від їх концентрації в електроліті

\begin{tabular}{|c|c|c|c|}
\hline Концентрація Ni в & \multicolumn{3}{|c|}{ Концентрація Сr в електроліті, г/л } \\
\cline { 2 - 4 } електроліті, г/л & 0 & 10 & 20 \\
\hline 0 & - & $1,15 \% \mathrm{Cr}$ & $1,33 \% \mathrm{Cr}$ \\
10 & $0,42 \% \mathrm{Ni}$ & $0,48 \% \mathrm{Cr}+0,64 \% \mathrm{Ni}$ & $1,18 \% \mathrm{Cr}+0,53 \% \mathrm{Ni}$ \\
20 & $1,27 \% \mathrm{Ni}$ & $0,86 \% \mathrm{Cr}+1,34 \% \mathrm{Ni}$ & $1,27 \% \mathrm{Cr}+1,74 \% \mathrm{Ni}$ \\
\hline
\end{tabular}

Також дифрактометричні дослідження показали наявність досить сильних переважних кристалографічних орієнтувань у покриттях: $<211>$ у покриттях без легування та у сплавах $\mathrm{Fe}-$ $\mathrm{Cr}$ i $<111>$ у сплавах Fe-Ni та Fe-Cr-Ni, які добре можна було спостерігати за відносною інтенсивністю дифракційних максимумів на дифрактограмах (навіть без використання специфічних методів текстурного аналізу). Тобто, введення хрому в сульфатний електроліт мало впливає на текстуру електроосадженого заліза (аксіальне орієнтування кристалів $<211>$ ), а введення нікелю навпаки приводить до різкої зміни переважного орієнтування на $<111>$.

Цікаво, що спільний вплив нікелю та хрому на процеси електроосадження проявляється у формування саме кристалографічної текстури, характерної для нікельвмісних сплавів, тобто для покриттів $\mathrm{Fe}-\mathrm{Cr}-\mathrm{Ni}$ саме присутність нікелю $є$ причиною зміни переважного орієнтування кристалів $3<211>$ на $<111>$ (рис. 1 ). 


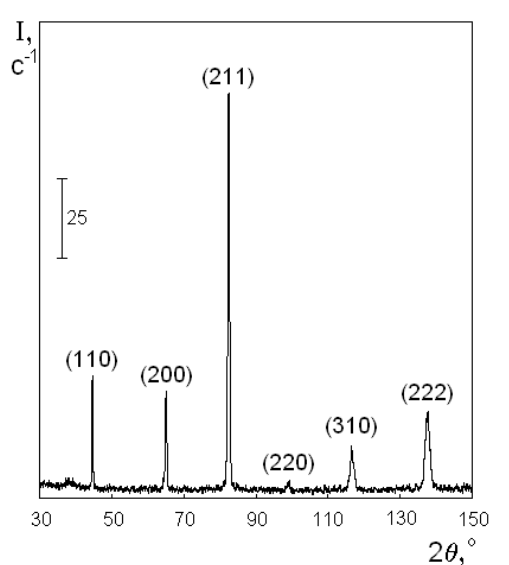

0 г/л $\mathrm{Cr} ; 0$ г/л

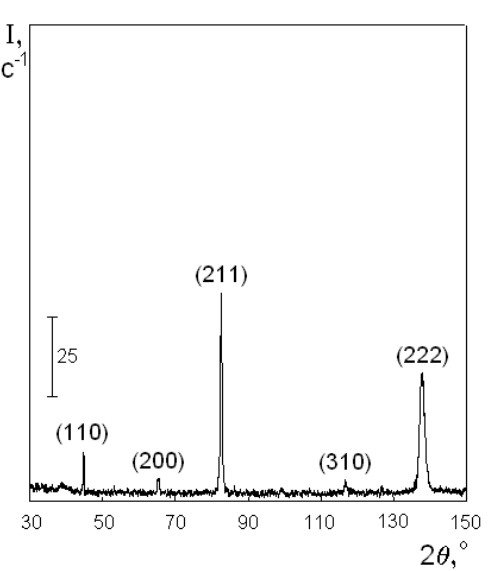

$\mathrm{Ni10}$ г/л $\mathrm{Cr} ; 10$ г/л

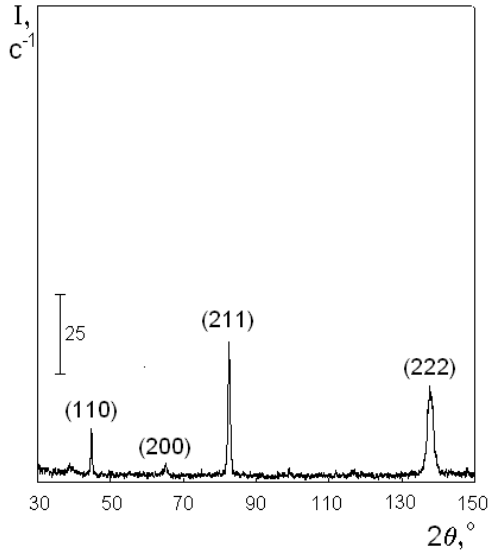

$\mathrm{Ni20}$ г/л $\mathrm{Cr} ; 20$ г/л $\mathrm{Ni}$

Puc. 1. Рентгенівські дифрактограми сплавів $\mathrm{Fe}-\mathrm{Cr}-\mathrm{Ni}$, електроосаджених з електролітів з різною концентрацією хрому та нікелю

Легування хромом та нікелем також приводить до помітних змін морфології поверхні досліджених покриттів, впливаючи на розміри та форму кристалів, як досліджених подвійних сплавів так і сплавів Fe-Cr-Ni (рис. 2). Введення нікелю в електроліт суттєво змінює тип структури покриттів - 3 дрібнокристалічної на сферолітну, а введення хрому у порівнянні із залізом без легування лише супроводжується утворенням більш розмірно однорідної структури, без суттєвих змін іiї типу. Морфологія поверхні сплавів $\mathrm{Fe}-\mathrm{Cr}-\mathrm{Ni}$, так як і сплавів $\mathrm{Fe}-\mathrm{Ni}$, представлена переважно сферолітами (рис. 2). Але в присутності хрому сферолітна структура покриттів дещо відрізняється - периферійна частина сферолітів стає менш розвиненою, а поверхня покриттів $є$ менш рельєфною, тобто наявність хрому дещо уповільнює процеси росту сферолітів. Таким чином, саме наявність нікелю є причиною формування сферолітів у досліджених сплаваx Fe-Cr-Ni.

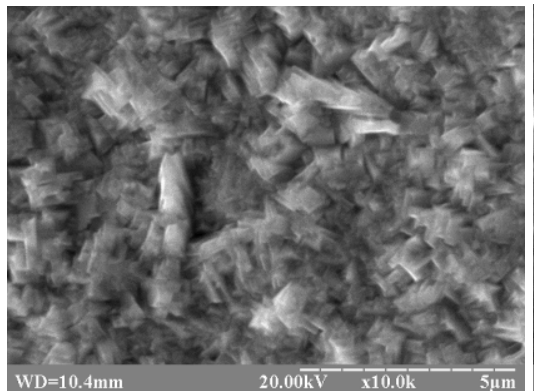

0 г/л $\mathrm{Cr} ; 0$ г/л $\mathrm{Ni}$

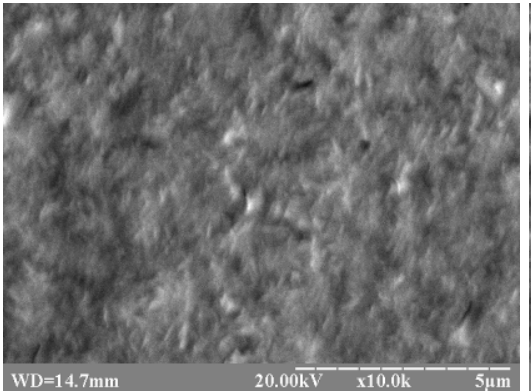

10 г/л $\mathrm{Cr} ; 10$ г/л $\mathrm{Ni}$

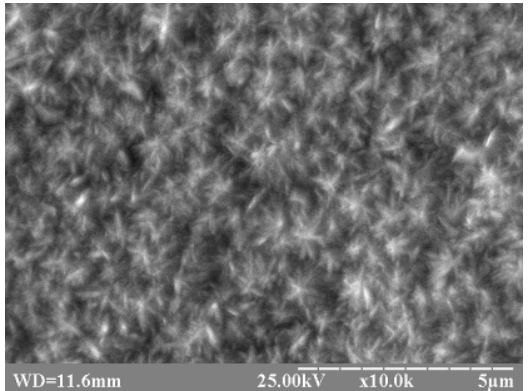

20 г/л $\mathrm{Cr} ; 20$ г/л $\mathrm{Ni}$

Рис. 2. Морфологія поверхні (×10000) сплавів $\mathrm{Fe}-\mathrm{Cr}-\mathrm{Ni}$, електроосаджених з електролітів з різною концентрацією хрому та нікелю

Вимірювання мікротвердості покриттів показали, що в подвійних сплавах хром і нікель, аналогічно з такими сплавами металургійного походження, приводять до зміцнення твердого розчину на основі заліза (табл. 2). Проте, вплив нікелю на мікротвердість $є$ менш вираженим у порівнянні із впливом хрому. Так, введення в електроліт 20 г/л нікелю приводить до збільшення мікротвердості від 2,73 ГПа до 3,75 ГПа, в той час як аналогічна концентрацією хрому викликає зростання мікротвердості до 4,32 ГПа. Спільний вплив нікелю та хрому при концентрації в електроліті 10+10 г/л на мікротвердість електроосаджених покриттів (4,01 ГПа) переважає вплив рівноцінної сумарної концентрації нікелю (20 г/л), але поступається впливу аналогі- 
чній концентрації хрому (3,75 та 4,32 ГПа відповідно). При цьому збільшення концентрації легуючих до 20+20 г/л несподівано приводить до зменшення рівня мікротвердості $(3,43$ ГПа), очевидно, причина цього полягає в тому, що підвищена кількість хрому дещо уповільнює формування сферолітної структури.

Таблиия 2. Мікротвердість електроосаджених покриттів HV 0,05 в залежності від концентрації легуючих елементів в електроліті, ГПа

\begin{tabular}{|c|c|c|c|}
\hline Концентрація Ni в & \multicolumn{3}{|c|}{ Конентрація Сr в електроліті, г/л } \\
\cline { 2 - 4 } електроліті, г/л & 0 & 10 & 20 \\
\hline 0 & 2,73 & 3,86 & 4,32 \\
10 & 3,27 & 4,01 & 3,70 \\
20 & 3,75 & 3,62 & 3,43 \\
\hline
\end{tabular}

Подальші вимірювання мікротвердості методом послідовного наближення для покриттів $\mathrm{Fe}-\mathrm{Cr}-\mathrm{Ni}$, одержаних з електролітів 3 проміжними концентраціями хрому та нікелю у межах досліджуваного діапазону, дозволили виявити локальний максимум мікротвердості 4,85 ГПа, який відповідає концентрації електроліту близько $12,5+12,5$ г/л і є досить високим показником у порівнянні із електроосадженим залізом без легування (2,73 ГПа). Морфологія поверхні цього сплаву Fe-Cr-Ni також характеризується наявністю сферолітів (рис. 3, a, б), проте більш периферійно розвинених, ніж наприклад, сплаву, одержаного 3 електроліту 10+10 г/л.

Аналізуючи мікроструктуру такого сплаву $\mathrm{Fe}-\mathrm{Cr}-\mathrm{Ni}$ у поперечному перетині (рис. 3, в), іiі безумовно можна віднести до дрібнодисперсних структур через малі розміри структурних складових (значно менші ніж 1 мкм), а за характером розташування кристалів та їх формою - до стовпчастих структур.

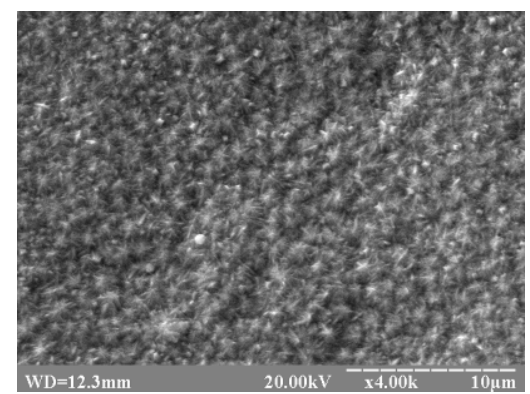

$\mathrm{a}(\times 4000)$

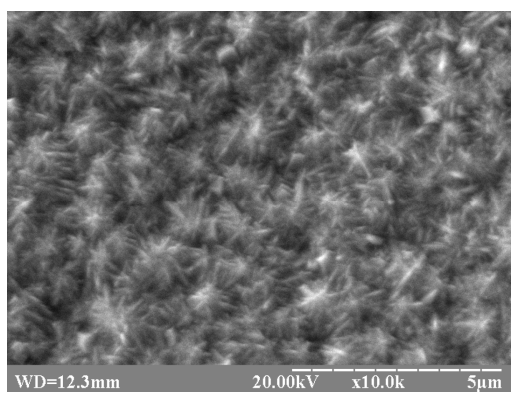

$6(\times 10000)$

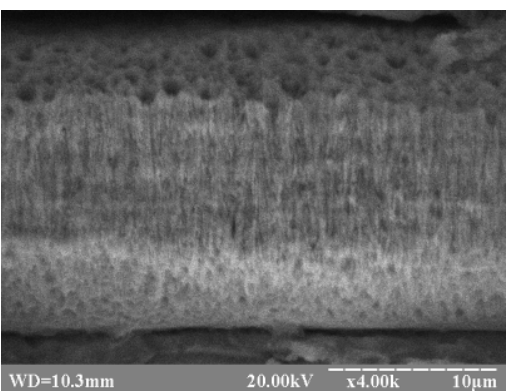

в $(\times 4000)$

Puc. 3. Морфологія поверхні (a, б) та мікроструктура у поперечному перетині (в) Fe$\mathrm{Cr}-\mathrm{Ni}$ сплаву, електроосадженого з електроліту, що містить 12,5 г/л хрому та 12,5 г/л нікелю

Враховуючи попередній досвід, високу мікротвердість сплаву $\mathrm{Fe}-\mathrm{Cr}-\mathrm{Ni}$, очевидно, можна пояснити комплексним впливом декількох структурних факторів, а саме: наявністю дрібнодисперсної сферолітної структури, утворенням твердих розчинів, формуванням вираженої аксіальної текстури $<111>$, а також високим рівнем залишкових макронапружень, характерних для електроосаджених покриттів. Але беручи до уваги досить високий зафіксований рівень мікротвердості сплаву $\mathrm{Fe}-\mathrm{Cr}-\mathrm{Ni}$, можна припустити, що у цьому випадку саме кристалографічна текстура має переважний внесок у таке зростання мікротвердості, оскільки вплив інших зазначених факторів зазвичай не є настільки високим.

3 точки зору кристалографічної текстури більш високі показники мікротвердості сплаву 3 об'ємноцентрованою кубічною решіткою $\alpha$-Fe 3 переважним орієнтуванням кристалів $<111>$ у порівнянні із орієнтуванням $<211>$ можна пояснити наступним чином. Аналізуючи щільність розташування атомів у кристалографічних площинах (111) та (211) (рис. 4), бачимо, що (211) є

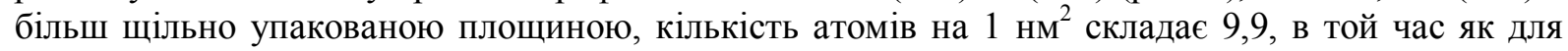


(111) цей показник складає 7,0. Тобто, площина (211) мала б сприяти збільшенню показників механічних властивостей матеріалу у напрямку, перпендикулярному до неї. Але розташування атомів є більш рівномірним у площині (111), де вони утворюють рівносторонні трикутники із стороною 4,05 $\AA$, а в площині (211) атоми утворюють прямокутники із сторонами 4,05 та 2,48 (рис. 4) (числові значення наведені для заліза без легування). Очевидно, більш рівномірне розташування атомів у кристалографічній площині (111) саме і $€$ причиною більш високого опору деформації при проникненні індентора у напрямку, перпендикулярному до неї. Підтвердженням цієї гіпотези можуть бути числові значення модуля Юнга для монокристалу заліза, 276 та 215 ГПа для кристалографічних напрямків $<111>$ та $<211>$ відповідно [17].

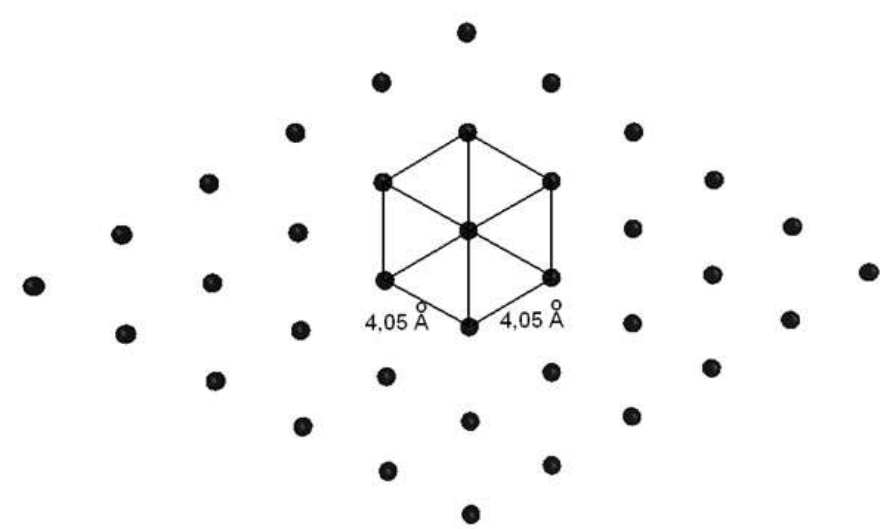

(111)

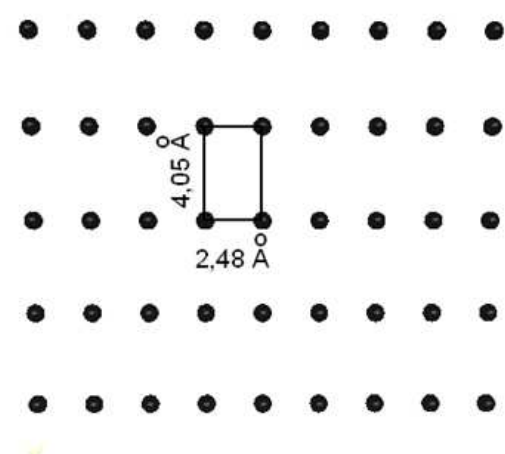

(211)

Puc. 4. Розташування атомів у площинах (111) та (211) кристалічної решітки $\alpha-\mathrm{Fe}$

Таким чином, враховуючи високий рівень мікротвердості поверхні, даний сплав $\mathrm{Fe}-\mathrm{Cr}$ $\mathrm{Ni}$ може бути рекомендований для практичного використання для відновлення розмірів і поверхневого зміцнення сталевих виробів. Для підтвердження можливості практичного застосування запропонованого сплаву були проведені додаткові дослідження інших його властивостей, зокрема зносостійкості, шорсткості поверхні, залишкових макронапружень, корозійних властивостей тощо, результати яких наведені в роботі [18] і показали цілком задовільний рівень цих характеристик.

\section{Висновки}

Для сплавів $\mathrm{Fe}-\mathrm{Cr}-\mathrm{Ni}$, що електроосаджуються з сульфатного електроліту, характерна сферолітна морфологія поверхні та виражена аксіальна текстура $<111>$. Максимальна мікротвердість досліджених покриттів завтовшки 15 мкм сягає 4,85 ГПа для сплавів, одержаних з електроліту, що містить хром та нікель у рівній концентрації близько 12,5 г/л кожного $з$ елементів, i $\epsilon$ досить високим показником у порівнянні із електроосадженим залізом без легування (2,73 ГПа для покриттів такої ж товщини). На підставі одержаних результатів виконано оптимізацію технології одержання електроосаджених покриттів сплавами $\mathrm{Fe}-\mathrm{Cr}-\mathrm{Ni}$ шляхом вибору оптимального складу електроліту і запропоновано ії практичне використання.

\section{Список використаної літератури}

1. Электролитическое осаждение железа / Ю. Н. Петров и др. Кишинев: Штиинца, 1990. 195 с.

2. Kolesnyk Ie. V., Bagliuk G. A. Regularities of influence of nickel and chromium on structure formation of electrodeposited iron. Materials Science. Non-Equilibrium Phase Transformations. 2016. № 4. P. 52-55. 
3. Wang F., Itoh K., Watanabe T. Relationship between the Crystallographic Structure of Electrodeposited Fe-Cr Alloy Film and Its Thermal Equilibrium Diagram. Materials Transactions. 2002. № 3. P. 439-442.

4. Колесник Е. В., Величко М. Т. Особенности формирования структуры электроосажденных Fe-Cr покрытий. Металознавство та термічна обробка металів. 2013. № 4. С. 64-68.

5. Wang F., Watanabe T. Preparation and characterization of the electrodeposited Fe-Cr alloy film. Materials Science and Engineering A. 2003. № 1-2. P. 183-190.

6. Nakamura K., Umetani M., Hayashi T. Electrodeposition of iron-rich Ni-Fe alloys from sulphate and chloride baths. Surface Technology. 1985. № 2. P. 111-119.

7. Колесник Е. В. Особенности структурообразования электроосажденных сплавов Fe-Ni. Hayковий вісник Національного гірничого університету. 2013. № 5. С. 62-66.

8. Mccrea J. L., Palumbo G., Hibbard G. D., Erb U. Properties and applications for electrodeposited nanocrystalline Fe-Ni alloys. Reviews on Advanced Materials Science. 2003. № 1. P. 252-258.

9. Колесник Е. В., Захаров И. Д. Структура электроосажденного железа, легированного марганцем. Металознавство та термічна обробка металів. 2013. № 1. С. 69-72.

10. Liu P., Yao C., Zhang W. et al. Electrochemical preparation of Fe-Mn alloy film in organic bath. Thin Solid Films. 2008. № 12. P. 3935-3939.

11. Kolesnyk Ie. V. Joint effect of chromium and nickel on surface morphology and preferred crystal orientations of electrodeposited iron-based coatings. Металлофизика и новейшие технологии. 2015. № 3. C. 347-354.

12. Chisholm C. U., Carnegie R. J. G. The electrodeposition of ternary iron-chromium-nickel alloys. A critical review. Electrodeposition and Surface Treatment. 1973. № 5. P. 367-394.

13. Vertes A., Watson A., Chisholm C. U. et al. A comparative study of Mossbauer spectroscopy and $\mathrm{X}$-ray diffraction for the elucidation of the microstructure of electrodeposited $\mathrm{Fe}-\mathrm{Cr}-\mathrm{Ni}$ alloys. Electrochimica Acta. 1987. № 12. P. 1761-1767.

14. Harris T. M., Whitney G. M., Croll I. M. The electrodeposition of Ni-Fe-Cr alloys for magnetic thin film applications. Journal of The Electrochemical Society. 1995. № 4. P. 1031-1034.

15. Sziráki L., Kuzmann E., El-Sharif M. et al. Electrochemical behavior of electrodeposited strongly disordered Fe-Ni-Cr alloys. Electrochemistry Communications. 2000. № 9. P. 619-625.

16. Колесник Е. В., Величко М. Т. Влияние технологических параметров на структурообразование электроосажденного сплава Fe-Cr-Ni. Теория и практика металлургии. 2014. № 3-6. C. $98-103$.

17. Dowling N. E. Mechanical behavior of materials. New Jersey, USA: Prentice Hall, 2012. 960 p.

18. Колесник $€$. В., Баглюк Г. А. Порівняльний аналіз структури та властивостей електрокристалізованих покриттів із заліза та сплаву $\mathrm{Fe}-\mathrm{Cr}-\mathrm{Ni}$. Металознавство та обробка металів. 2016. № 1. С. 23-28.

\section{OPTIMIZATION OF THE TECHNOLOGY FOR ELECTRODEPOSITION OF Fe-Cr-Ni COATINGS ON CRITERIA OF SURFACE MICROHARDNESS Kolesnyk Ie.V., Bagliuk G.A., Yeremenko A.P., Ysenko A.S., Robak E.S.}

\footnotetext{
Abstract

Electrodeposited coatings have been widely used in industry, in particular electrodeposited iron and some of its alloys are used for restoration of the dimensions of worn-out steel machine parts of various purpose and sizes. Coatings obtained by electrodeposition usually have a higher hardness compared to materials of metallurgical origin, that is, the restoration of parts using electrodeposited iron-based alloys (e.g. Fe-Cr, Fe-Ni, Fe-Mn, Fe-Cr-Ni) simultaneously leads to their surface hardening, which is an additional advantage of this method of machine parts restoration. For the further enhancement of properties of electrodeposited iron-based alloys coatings working in the
} 
conditions of friction and wear, the optimization of the technology of their production (electrolyte composition, parameters of the electrodeposition process) is an urgent task.

The aim of this work was to increase the level of properties of electrodeposited economically alloyed $\mathrm{Fe}-\mathrm{Cr}-\mathrm{Ni}$ coatings by optimizing the technology of their production, in particular the composition of the electrolyte.

Alloying of electrodeposited iron with chromium and nickel leads to changes in microstructure, surface morphology, crystallographic texture and increase of microhardness of coatings. The high microhardness of the Fe-Cr-Ni alloy can be explained by the complex influence of several structural factors, namely: the presence of fine spherulite structure, the formation of solid solutions, the formation of a pronounced axial texture, and a high level of residual macrostresses. It has been suggested that in this case crystallographic texture has a major contribution to the increase of microhardness of coatings. The arrangement of atoms is more uniform in the crystallographic plane (111), where they form equilateral triangles with a side of $4.05 \AA$, than in the plane (211), where the atoms form rectangles with sides of 4.05 and $2.48 \AA$. Probably, a more uniform arrangement of the atoms can be the reason of the higher deformation resistance during the surface penetration by the indenter in a direction perpendicular to the plane (111).

Fe-Cr-Ni alloys electrodeposited from sulphate electrolyte are characterized by spherulitic surface morphology and pronounced axial texture $\langle 111>$. The maximum microhardness of the investigated coatings with a thickness of $15 \mu \mathrm{m}$ reaches $4.85 \mathrm{GPa}$ for the alloys obtained from the electrolyte of the optimal composition containing chromium and nickel at the equal concentrations of about $12.5 \mathrm{~g} / 1$ of each element, and it is quite high value compared to electrodeposited iron without alloying (2.73 GPa for coatings of the same thickness). On the basis of the obtained results, the technology for obtaining electrodeposited $\mathrm{Fe}-\mathrm{Cr}-\mathrm{Ni}$ alloys coatings was enhanced by optimizing the composition of the electrolyte, and its practical usage was suggested.

\section{References}

[1] Petrov Yu.N., Guryanov G.V., Bobanova Zh.I. et al. Elektroliticheskoe osazhdenie zheleza [Electrolitic deposition of iron]. Chisinau: Shtiintsa, 1990, 195 p (in Russian).

[2] Kolesnyk Ie.V., Bagliuk G.A. Regularities of influence of nickel and chromium on structure formation of electrodeposited iron. Materials Science. Non-Equilibrium Phase Transformations, 2016, no. 4, pp. 52-55.

[3] Wang F., Itoh K., Watanabe T. Relationship between the Crystallographic Structure of Electrodeposited Fe-Cr Alloy Film and Its Thermal Equilibrium Diagram. Materials Transactions, 2002, no. 3, pp. 439-442.

[4] Kolesnyk Ie.V., Velychko M.T. Osobennosti formirovaniya struktury electroosazhdennyh Fe-Cr pokrytiy [Features of structure formation of electrodeposited Fe-Cr coatings]. Metaloznavstvo ta Termichna Obrobka Metaliv - Metals Science and Heat Treatment of Metals, 2013, no. 4, pp. 6468 (in Russian).

[5] Wang F., Watanabe T. Preparation and characterization of the electrodeposited Fe-Cr alloy film. Materials Science and Engineering A, 2003, vol. 349, no. 1-2, pp. 183-190.

[6] Nakamura K., Umetani M., Hayashi T. Electrodeposition of iron-rich Ni-Fe alloys from sulphate and chloride baths. Surface Technology, 1985, no. 2, pp. 111-119.

[7] Kolesnyk Ie.V. Osobennosti strukturoobrazovaniya elektroosazhdennyh splavov Fe-Ni [Features of structure formation of electrodeposited alloys Fe-Ni]. Naukovyi Visnyk Natsionalnoho Hirnychoho Universytetu - Scientific Bulletin of National Mining University, 2013, no. 5, pp. 62-66 (in Russian).

[8] Mccrea J.L., Palumbo G., Hibbard G.D., Erb U. Properties and applications for electrodeposited nanocrystalline Fe-Ni alloys. Reviews on Advanced Materials Science. 2003, no. 1, pp. 252-258.

[9] Kolesnyk Ie.V., Zakharov I.D. Struktura electroosazhdennogo zheleza, legirovannogo margantsem [Structure of electrodeposited iron alloyed with manganese]. Metaloznavstvo ta Termichna 
Obrobka Metaliv - Metals Science and Heat Treatment of Metals, 2013, no. 1, pp. 69-72 (in Russian).

[10] Liu P., Yao C., Zhang W. et al. Electrochemical preparation of Fe-Mn alloy film in organic bath. Thin Solid Films, 2008, no. 12, pp. 3935-3939.

[11] Kolesnyk Ie.V. Joint effect of chromium and nickel on surface morphology and preferred crystal orientations of electrodeposited iron-based coatings. Metallofizika i Noveishie Tekhnologii-Metal Physics and Advanced Technologies, 2015, no. 3, pp. 347-354.

[12] Chisholm C.U., Carnegie R.J.G. The electrodeposition of ternary iron-chromium-nickel alloys. A critical review. Electrodeposition and Surface Treatment, 1973, no. 5, pp. 367-394.

[13] Vertes A., Watson A., Chisholm C.U. et al. A comparative study of Mossbauer spectroscopy and $\mathrm{X}$-ray diffraction for the elucidation of the microstructure of electrodeposited $\mathrm{Fe}-\mathrm{Cr}-\mathrm{Ni}$ alloys, Electrochimica Acta, 1987, no. 12, pp. 1761-1767.

[14] Harris T.M., Whitney G.M., Croll I.M. The electrodeposition of Ni-Fe-Cr alloys for magnetic thin film applications. Journal of the Electrochemical Society, 1995, no. 4, pp. 1031-1034.

[15] Sziráki L., Kuzmann E., El-Sharif M. et al. Electrochemical behavior of electrodeposited strongly disordered Fe-Ni-Cr alloys. Electrochemistry Communications, 2000, vol. 2, no. 9, pp. 619625.

[16] Kolesnyk Ie.V., Velychko M.T. Vliyanie tehnologicheskih parametrov na strukturoobrazovanie elektroosazhdennogo splava Fe-Cr-Ni [Influence of technological parameters on structure formation of the electrodeposited Fe-Cr-Ni alloy]. Teoriya i Praktika Metallurgii - Theory and Practice of Metallurgy, 2014, no. 3-6, pp. 98-103 (in Russian).

[17] Dowling N.E. Mechanical behavior of materials. New Jersey, USA: Prentice Hall, 2012, 960 p.

[18] Kolesnyk Ie.V., Bagliuk G.A. Porivnialnyy analiz struktury ta vlastyvostey elektrokrystalizovanyh pokryttiv iz zaliza ta splavu Fe-Cr-Ni [Comparative analysis of structure and properties of electrodeposited iron and Fe-Cr-Ni alloy coatings]. Metaloznavstvo ta Obrobka Metaliv-Metals Science and Treatment of Metals, 2016, no. 1, pp. 23-28 (in Ukrainian). 